\title{
Papillary thyroid cancer and thyroid stimulating hormone: does sex matter?
}

\author{
O. Chernenko ${ }^{1}$, O. Sulaieva ${ }^{2}$ \\ ${ }^{1}$ Ukrainian Research and Practical Center of Endocrine Surgery, Kyiv; \\ ${ }^{2}$ Laboratory of pathology "CSD Health Care", Kyiv; \\ e-mail: oksana.sulaieva@gmail.com; o.sulaieva@csd.com.ua
}

The relation between histopathological characteristics of papillary thyroid cancer (PTC) and thyroid functioning in patients of different sex was assessed. Levels of thyroid stimulating hormone (TSH) and thyroid hormones (fT3 and fT4) were measured in 576 patients (468 females and 108 males) with histologically confirmed PTC. Extrathyroid extension (ETE) of PTC, lymphovascular invasion (LVI) and lymph node metastasis (LNM) were assessed in patients of different sex. In addition, age, histological type and Hashimoto's thyroiditis (HT) were considered. We did not find sex differences in PTC staging. However, females demonstrated smaller tumor size and higher microcarcinoma rate, whereas PTC in men was related to a higher LNM incidence. Coexisting HT was found in $33.3 \%$ of the observed patients. HT rate was significantly higher in females than in males and was associated with elevated TSH, though, there was no statistically significant relationship between HT and thyroid hormone levels. Coexisting HT significantly decreased the risk of ETE $(O R=0.67 ; 95 \%$ CI 0.44-1.00; $P=0.05)$ and $L N M(O R=0.59 ; 95 \%$ CI 0.37-0.94; $P$ $=0.028$ ) among males with PTC. However, there was no significant impact of HT on ETE and LNM in females with PTC. The present study showed sex-related differences in TSH levels and microcarcinoma incidence associated with high rate of coexisting HT in females. Coexisting HT was associated with lower rate of LNM and ETE in males that could reflect a potentially protective role of HT in PTC progression.

Key words: papillary thyroid cancer, thyroid stimulating hormone, Hashimoto's thyroiditis, sex differences.

\section{INTRODUCTION}

Papillary thyroid cancer (PTC) accounts more than $80 \%$ of all thyroid malignancies, making it the most common type of endocrine cancers [1-3]. The incidence of PTC is about 3 times higher in females than in males [3-5]. Specific clinical and pathological differences between male and female PTC patients have been reported [5-8]. There are some data demonstrating that female patients with PTC had an earlier age of onset, whereas males tend to have a more aggressive disease with higher mortality $[5,8]$. However, the reasons for these sex differences are unclear. As the peak incidence of PTC was established in females of 40-49 years of age, there were several studies defining the association of PTC with reproductive factors [3, 7]. By now there is no strong evidence for hormonal, menstrual or reproductive factors impact on PTC in women [7]. On the other hand, thyroid stimulating hormone (TSH) is considered as an important additional risk factor in different types of thyroid pathology [9]. The TSH concentration is higher in women than in men and TSH secretion depends on age in women only [5]. In addition, it was shown that TSH plays a role in nodular thyroid disease and is a risk factor of thyroid cancer, including PTC [10]. However, the comprehensive evaluation of the TSH levels impact in PTC development and prognosis is controversial. A number of studies recorded an increased risk of thyroid cancer associated with elevated TSH levels $[9,11,12]$. However, there is an opposite point of view which is supported by many other studies, or not any relations between TSH and PTC are reported [10, 12,

(C) O. Chernenko, O. Sulaieva 
13]. Anyway, it is still unclear if there are any relations or causal effects of TSH levels with PTC progression in patients of different sex. In addition, assessment of hormone levels in PTC patients is important in terms of age and sexassociated differences in Hashimoto thyroiditis (HT) rate $[14,15]$. The aim of this study was to compare TSH and thyroid hormone levels impact on PTC pathological features between the sexes.

\section{METHODS}

We conducted a retrospective one-center cohort study enrolling patients with PTC who were observed at Ukrainian Research and Practical Center for Endocrine Surgery. Enrolled cases met the following criteria: 1) primary diagnosed and histologically confirmed PTC in line with the updated WHO classification (2017) [16]; 2) measurements of TSH and thyroid hormone levels were done prior to surgery; 3) patients' age was 21 years or older at the time of hospital admission. Exclusion criteria were the following: 1) cases with any prior cancers recorded at the date of diagnosis of thyroid cancer; 2) patients who received hormonal replacement therapy prior to diagnostics and operation; 3) Graves' disease; 4) pregnancy. A total of 576 eligible cases of PTC were identified. In this study, PTC patients were sub-classified into male and female groups.

Information on clinical and laboratory data as well as tumor histology were collected. The following characteristics were considered during grossing and histopathological examination: unifocal/multifocal growth, coexisting HT, extrathyroid extention (ETE), intrathyroid invasion (lymphovascular or in surrounding tissues), lymph nodes metastasis (LNM). Histological type of PTC was defined according to the WHO classification (2017) [16]. Pathological staging was performed in line with the American Joint Committee on Cancer TNM staging system (8th Edition; 2017) [17]. Diagnosis of HT was based on clinical and sonographic data, confirmed by serum autoantibodies to thyroglobulin and
TPO and by histological evaluation of slides. The following criteria for HT diagnostics were used: diffuse lymphocyte infiltration, lymphoid follicles with germinal centers and Hürthle cell changes [18]. To measure the serum concentrations of TSH and thyroid hormones levels Roche Cobas e411 automatic analyzer, the manufacturer's reagents and calibration kit were used. The normal ranges were considered as $0.04-4.0$ $\mu \mathrm{U} / \mathrm{ml}$ for serum concentrations of TSH, 2.0-4.4 $\mathrm{pg} / \mathrm{ml}$ for fT3 and $0.93-1.71 \mathrm{ng} / \mathrm{dl}$ for fT4. The predictive value of clinical features, laboratory data and histopathological findings in terms of PTC progression (ETE, LNM, stage) were explored and compared between male and female patients. Data assessment was conducted using MedCalc statistical software (MedCalc Software Inc, Belgium) and represented as $\mathrm{M} \pm \mathrm{SEM}$. The groups characteristics were compared using the chi-square test. To assess the association hormone levels and PTC characteristics the odds ratios (OR) with $95 \%$ confidence interval $(95 \%$ CI) were calculated.

\section{RESULTS AND DISCUSSION}

There were 468 females $(81.3 \%)$ and 108 males (18.7\%) among observed patients with PTC aged $47.5 \pm 0.65(95 \%$ CI 46.2-48.7) and $45.05 \pm$ 1.39 (95\% CI 42.3-47.8) years old respectively. Most of the patients with PTC were euthyroid with fT 3 and fT 4 levels comprising $3.82 \pm 0.14$ $\mathrm{pg} / \mathrm{ml}$ and $1.26 \pm 0.05 \mathrm{ng} / \mathrm{dl}$, respectively. Although TSH levels among enrolled cohort were within the normal range, the distribution of TSH variables was right-skewed, and more than $80 \%$ of observed patients had TSH level under 2.5 $\mathrm{mkU} / \mathrm{ml}$. We did not find statistical differences in fT3 and fT4 levels between sexes, but serum TSH concentration was significantly higher in females (Table 1). In addition, there were some peculiarities of age-related TSH dynamics in male and female patients with PTC. Moreover, we reported sex-related differences in PTC size $(1.57 \pm 0.06$ vs $1.89 \pm 0.13 \mathrm{~cm}$ in women and men, respectively, $\mathrm{P}=0.02$ ). However, we did 
Clinical, laboratory and histopathological characteristics of PTC in patients of different sex

\begin{tabular}{|c|c|c|c|c|c|c|c|}
\hline Characteristics & \multicolumn{2}{|c|}{ Overall } & \multicolumn{2}{|c|}{ Females } & \multicolumn{2}{|c|}{ Males } & $\mathrm{P}$ \\
\hline Number & \multicolumn{2}{|c|}{576} & 468 & $81.2 \%$ & 108 & $18.8 \%$ & \\
\hline Age (years old) & \multirow{2}{*}{\multicolumn{2}{|c|}{$\begin{array}{l}47.1 \pm 0.59 \\
45.89-48.2\end{array}$}} & \multirow{2}{*}{\multicolumn{2}{|c|}{$\begin{array}{c}47.5 \pm 0.64 \\
46.23-48.77\end{array}$}} & \multirow{2}{*}{\multicolumn{2}{|c|}{$\begin{array}{c}45.1 \pm 1.39 \\
42.3-47.8\end{array}$}} & $\mathrm{P}=0.104$ \\
\hline & & & & & & & \\
\hline Under 55 years old & 414 & $71.9 \%$ & 342 & $73.1 \%$ & 72 & $66.7 \%$ & $\mathrm{P}=0.224$ \\
\hline Older 55 years old & 162 & $28.1 \%$ & 126 & $26.9 \%$ & 36 & $33.3 \%$ & \\
\hline \multicolumn{8}{|c|}{ Tumor characteristics } \\
\hline Tumor size (in $\mathrm{cm}$ ) & \multirow{2}{*}{\multicolumn{2}{|c|}{$\begin{array}{c}1.63 \pm 0.06 \\
1.52-1.74\end{array}$}} & \multirow{2}{*}{\multicolumn{2}{|c|}{$\begin{array}{c}1.57 \pm 0.06 \\
1.45-1.69\end{array}$}} & \multirow{2}{*}{\multicolumn{2}{|c|}{$\begin{array}{c}1.89 \pm 0.13 \\
1.61-2.15\end{array}$}} & $\mathrm{P}=0.020$ \\
\hline & & & & & & & \\
\hline \multicolumn{8}{|l|}{ Multifocality } \\
\hline Absent & 433 & $75.2 \%$ & 349 & $74.6 \%$ & 84 & $77.8 \%$ & $\mathrm{P}=0.568$ \\
\hline Present & 143 & $24.8 \%$ & 119 & $25.4 \%$ & 24 & $22.2 \%$ & \\
\hline \multicolumn{8}{|c|}{ Histological type of PTC } \\
\hline $\begin{array}{l}\text { Papillary } \\
\text { microcarcinoma }\end{array}$ & 221 & $38.4 \%$ & 193 & $41.2 \%$ & 28 & $25.9 \%$ & $\mathrm{P}=0.015$ \\
\hline Conventional type & 166 & $28.80 \%$ & 122 & $26.1 \%$ & 44 & $40.7 \%$ & \\
\hline Tall cell variant & 20 & $3.50 \%$ & 17 & $3.6 \%$ & 3 & $2.8 \%$ & \\
\hline Sclerosing & 10 & $1.70 \%$ & 8 & $1.7 \%$ & 2 & $1.9 \%$ & \\
\hline Oncocytic & 35 & $6.10 \%$ & 32 & $6.8 \%$ & 3 & $2.8 \%$ & \\
\hline Solid & 33 & $5.70 \%$ & 26 & $5.6 \%$ & 7 & $6.5 \%$ & \\
\hline Follicular & 91 & $15.80 \%$ & 70 & $15.0 \%$ & 21 & $19.4 \%$ & \\
\hline \multicolumn{8}{|c|}{ Extrathyroidal extension } \\
\hline Absent & 414 & $71.9 \%$ & 342 & $73.1 \%$ & 72 & $66.6 \%$ & $\mathrm{P}=0.223$ \\
\hline Present & 162 & $28.1 \%$ & 126 & $26.9 \%$ & 36 & $33.3 \%$ & \\
\hline \multicolumn{8}{|c|}{ Lymph Node Metastasis } \\
\hline Absent & 462 & $80.2 \%$ & 387 & $82.7 \%$ & 75 & $69.4 \%$ & $\mathrm{P}=0.003$ \\
\hline Present & 114 & $19.8 \%$ & 81 & $17.3 \%$ & 33 & $30.6 \%$ & \\
\hline \multicolumn{8}{|c|}{ TNM stage } \\
\hline I & 474 & $82.3 \%$ & 386 & $82.5 \%$ & 88 & $81.5 \%$ & $\mathrm{P}=0.925$ \\
\hline II & 94 & $16.3 \%$ & 75 & $16.0 \%$ & 19 & $17.6 \%$ & \\
\hline III & 8 & $1.4 \%$ & 7 & $1.5 \%$ & 1 & $0.9 \%$ & \\
\hline \multicolumn{8}{|c|}{ Coexisting HT } \\
\hline Absent & 384 & $66.7 \%$ & 293 & $28.4 \%$ & 91 & $79 \%$ & $\mathrm{P}<0.0001$ \\
\hline Present & 192 & $33.3 \%$ & 175 & $41.6 \%$ & 17 & $21 \%$ & \\
\hline \multicolumn{8}{|c|}{ Hormone levels } \\
\hline TSH $(\mu \mathrm{IU} / \mathrm{ml})$ & \multirow{2}{*}{\multicolumn{2}{|c|}{$\begin{array}{c}1.71 \pm 0.05 \\
1.62-1.80\end{array}$}} & \multicolumn{2}{|c|}{$1.75 \pm 0.05$} & \multirow{2}{*}{\multicolumn{2}{|c|}{$\begin{array}{c}1.53 \pm 0.08 \\
1.36-1.69\end{array}$}} & $\mathrm{P}=0.005$ \\
\hline & & & 1.6 & & & & \\
\hline fT3 $(\mathrm{pg} / \mathrm{ml})$ & \multicolumn{2}{|c|}{$3.65 \pm 0.09$} & \multicolumn{2}{|c|}{$3.61 \pm 0.09$} & \multicolumn{2}{|c|}{$3.72 \pm 0.37$} & $\mathrm{P}=0.605$ \\
\hline & \multicolumn{2}{|c|}{$3.44-3.84$} & 3.3 & & & & \\
\hline fT4 (ng/dl) & 1.2 & 0.02 & 1.2 & .02 & & & $\mathrm{P}=0.127$ \\
\hline & 1.1 & 1.25 & 1.1 & 241 & 1.1 & 37 & \\
\hline
\end{tabular}


not find size-related differences of serum TSH, fT3 and fT4 levels in patients of different sex.

Among the entire cohort, the rate of LNM was $19.8 \%$ (114 of 576 patients). Risk of LNM was closely related to sex and was much higher in males $(\mathrm{P}=0.0014)$. In addition, the frequency of LNM was closely associated with histological type of PTC $(\mathrm{P}<0.0001)$. The most frequent LNM was found in patients with diffuse-sclerotic and tall cell variant of PTC (53\%). The conventional type of PTC comprised 39\% LNM, the follicular variant - about $11 \%$, and the lowest incidence of LNM was found among patients with papillary microcarcinoma $(8 \%)$. However, these differences were not related to TSH levels.

Assessing sex-related differences in histological types and size of PTC, we found that females demonstrated much higher incidence of the microcarcinoma compared to males $(46 \%$ vs $34 \%$, respectively; $\mathrm{P}=0.044)$; though there were no sex-related peculiarities of histological pattern of PTC. In addition, hormone levels were similar in patients with papillary microcarcinoma and PTC sized more than $10 \mathrm{~mm}$ in both male and female patients. Moreover, TSH levels did not affect TNM stage of PTC $(\mathrm{OR}=1.229$; 95\% CI 0.79-1.89; $\mathrm{P}=0.35$ ).

Although there were no significant differences in ranges of fT3 and fT 4 in patients of different sex, it was found that high-normal (more than 2,5 $\mu \mathrm{IU} / \mathrm{ml}$ ) and high (more than 4.2 $\mu \mathrm{IU} / \mathrm{ml}$ ) levels of TSH were more frequent in females than that in males $(\mathrm{P}=0.03)$. This was due to a higher rate of the PTC-HT coexistence in females. Coexisting HT was found in 33.3\% of the observed cohort with PTC. HT rate was significantly higher $(\mathrm{P}<0.0001)$ in females than in males $(41.6 \%$ vs $21 \%)$. Assessing the impact of HT on PTC, we noticed that coexisting HT is associated with higher frequency of microcarcinoma $(P=0.015)$. Naturally, the size of PTC was lower in patients with coexisting HT $(\mathrm{P}=0.007)$. In addition, coexisting HT affected TSH levels (Fig. 1); that was significantly higher in PTC patients with coexisting HT compared to patients with PTC alone $(\mathrm{P}<0.001)$; though, we did not find a statistically important relationship between HT and fT3/fT4 levels in patients with PTC.

In addition, we found that presence of HT was associated with a dip in metastasis rate in patients with PTC $(\mathrm{P}=0.035)$. The rate of LNM in patients with coexisting HT was almost twice lower than in those who had not any features of HT (14.6\% vs $22.4 \%$, respectively). Presence of HT significantly decreased risk of ETE (OR = $0.67 ; 95 \%$ CI $0.44-1.00 ; \mathrm{P}=0.05)$ and metastasis into $\mathrm{LN}(\mathrm{OR}=0.59 ; 95 \%$ CI $0.37-0.94 ; \mathrm{P}$ $=0.028$ ) among males with PTC. However, we did not find a significant impact of coexisting HT on the rate of both lymph node metastasis $(\mathrm{OR}=0.81(95 \%$ CI $0.48-1.34 ; \mathrm{P}=0.407)$ and extrathyroid expansion $(\mathrm{OR}=2.0(95 \% \mathrm{CI}$ $0.69-5.72 ; \mathrm{P}=0.19)$ in females. This could be related to some sex-specific features of PTC progression and invasiveness and have to be clarified in future investigations.

This finding allows to suggest that elevation of serum TSH concentration is mostly the consequence of coexisting HT rather than the cause of thyroid dysfunction, malignant transformation and progression of PTC.

The sex disparity in incidence, aggressiveness and prognosis is well established for thyroid cancer but the mechanisms of these differences are not fully understood. Previous investigations showed that females with PTC had an earlier age of onset, but males tend to have a more aggressive disease with higher mortality $[5,6]$. In contradiction with previous reports, the current study showed no significant difference in age of onset, multifocality, and stages between male and female groups. In addition, we did not find sex differences in fT3 and fT4 levels; though the serum concentration for TSH was statistically higher in females with PTC. This peculiarity was associated with a higher rate of coexisting HT. In fact, there have been numerous studies examined the relationship between serum TSH concentration and HT $[17,20]$. Although there are some debates about the role of HT in PTC development, there is a strong evidence for the 

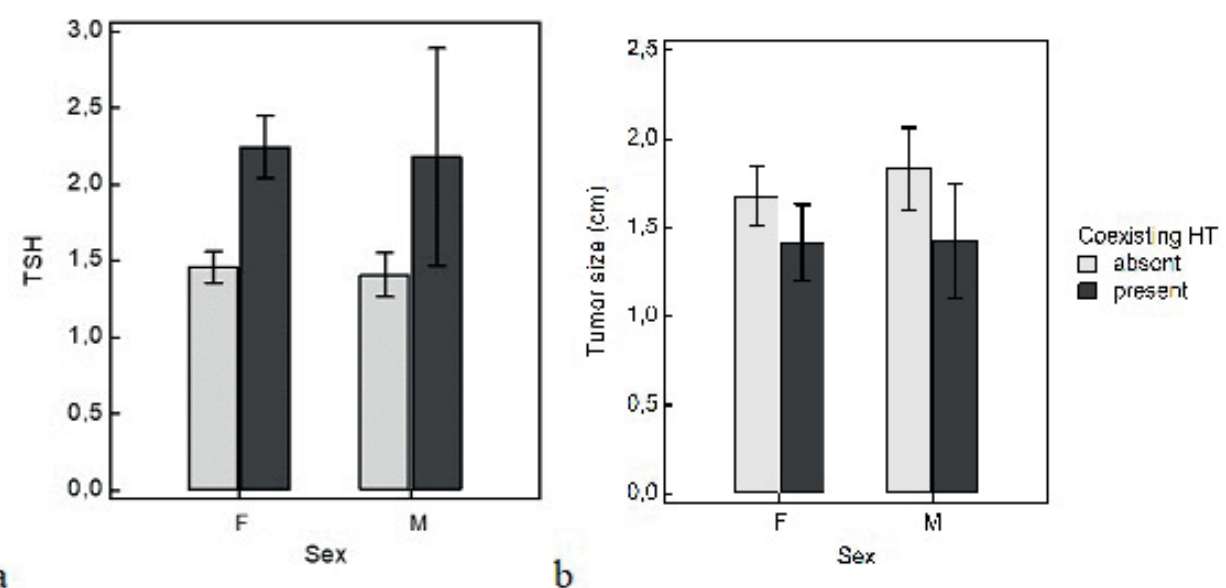

Impact of coexisting Hashimoto's thyroiditis (HT) on thyroid stimulating hormone (TSH) levels and tumor size in patients of different sex.

a - relationship between patients' sex and TSH levels with regard to coexisting HT. b - relationship between patients' sex and tumor size with regard to coexisting HT

role of autoimmune inflammation in malignancy $[19,20]$. In addition, we found a significant disparity in such PTC characteristics as size, ETE and LNM, and the relationship between these variables with coexisting HT. Interestingly, the higher rate of microcarcinoma and low frequency of LNM in females were associated with coexisting HT. This potentially demonstrates the reverse relationship between HT and PTC progression features. Partially, this observation could be related with immune cells infiltration of tumors [18, 20].

We found that a higher rate of LNM in males was associated with low coincidence of HT with PTC, this supports our concept of the relationship between HT and PTC. The protective effect of coexisting HT was demonstrated in terms of LNM and ETE risks. This allows us to suppose that HT attenuates PTC progression in males, that stimulates studying sex-related mechanisms of PTC development and progression. In fact, some authors postulate that lymphocytic infiltrate of HT may be an immunological response with a cancer-retarding effect, contributing to a favorable outcome of PTC $[16,20]$. This concept could explain the negative feedback between PTC-HT coexistence and metastasis rate in males.
The present study showed sex-related differences in TSH levels and microcarcinoma incidence due to high HT rate in females. Coexisting HT was associated with a lower rate of LNM and ETE in males, this could reflect a potentially protective role of HT in PTC progression.

The authors of this study confirm that the research and publication of the results were not associated with any conflicts regarding commercial or financial relations, relations with organizations and/or individuals who may have been related to the study, and interrelations of coauthors of the article.

\section{О. Черненко, О. Сулаева}

\section{ПАПИЛЛЯРНЫЙ РАК ЩИТОВИДНОЙ ЖЕ- ЛЕЗЫ И ТИРЕОТРОПНЫЙ ГОРМОН: ПОЛО- ВЫЕ РАЗЛИЧИЯ}

Проанализирована взаимосвязь патогистологических характеристик папиллярного рака щитовидной железы (ПРЩЖ) и показателей функциональной активности этого органа у пациентов разного пола (468 женщин и 108 мужчин). Исследовали содержание тиреотропного гормона (ТТГ), свободного трийодтиронина и тироксина (fT3 и fT4) в сыворотке крови. Оценивали стадию, частоту экстратиреоидной и лимфоваскулярной инвазии, а также метастазирования в лимфатические узлы. Кроме того, при анализе половых различий учитывали возраст, гистологический тип ПРЩЖ и наличие аутоиммунного 
тиреоидита (АИТ). В работе не обнаружено статистически значимых различий стадии ПРЩЖ у пациентов разного пола. У женщин были зарегистрированы меньший размер опухоли и более высокая частота микрокарцином, в то время как у мужчин зафиксирована более высокая частота МЛУ. Сопутствующий АИТ был обнаружен у $33,3 \%$ пациентов, его частота была значительно выше у женщин, что сопровождалось повышением содержания ТТГ, хотя статистически значимой взаимосвязи между АИТ и содержанием тиреоидных гормонов не выявлено. Сопутствующий АИТ значительно снижал риск экстратиреоидной инвазии $(\mathrm{OR}=0,67 ; 95 \%$ ДИ 0,44-1,00; $\mathrm{P}=0,05)$ и МЛУ $(\mathrm{OR}=0,59 ; 95 \%$ ДИ 0,37-0,94; $\mathrm{P}=0,028)$ у пациентов мужского пола с ПРЩЖ, но не оказывал влияние на показатели инвазивности у женщин. Таким образом, выявлены половые различия сывороточного содержания ТТГ и частоты микрокарциномы, что ассоциировано с высокой частотой сопутствующего АИТ у женщин. Сопутствующий АИТ у мужчин был сопряжен со снижением риска экстратиреоидной инвазии и МЛУ, что может отражать защитную роль АИТ в прогрессировании заболевания.

Ключевые слова: папиллярный рак щитовидной железы, тиреотропный гормон, аутоиммунный тиреоидит, половые различия.

\section{О. Черненко ${ }^{1}$, О. Сулаєва ${ }^{2}$}

\section{ПАПІЛЯРНИЙ РАК ЩИТОПОДІБНОЇ ЗАЛО- ЗИ І ТИРЕОТРОПНИЙ ГОРМОН: СТАТЕВІ РОЗБІЖНОСТI}

Проаналізовано взаємозв'язок патогістологічних характеристик папілярного раку щитоподібної залози (ПРЩЗ) і показників функціональної активності цього органа у пацієнтів різної статі (468 жінок і 108 чоловіків). Досліджували вміст тиреотропного гормону (ТТГ), вільного трийодтироніну і тироксину (fT3 i fT4) у сироватці крові. Оцінювали стадію, частоту екстратиреоїдного поширення (ЕТП) та лімфоваскулярної інвазії (ЛВІ), частоту метастазування у лімфатичні вузли (МЛУ). Крім того, при аналізі статевих відмінностей враховували вік, гістологічний тип ПРЩЗ і наявність аутоімунного тиреоїдиту (AIT). Не було виявлено статистично значущих відмін стадії ПРЩЖ у пацієнтів різної статі. У жінок були зареєстровані менший розмір пухлини і більш висока частота мікрокарцином, в той час як у чоловіків - більш високу частота МЛУ. Супутній AIT був виявлений у $33,3 \%$ пацієнтів, його частота була значно вищою у жінок, що супроводжувалося зростанням вмісту ТТГ, хоча при цьому зв'язку між AIT і концентрацією тиреоїдних гормонів не було виявлено. Супутній AIT значно знижував ризик екстратиреоїдного поширення $(\mathrm{OR}=0,67 ; 95 \%$ ДI $0,44-1,00 ; \mathrm{P}=0,05)$ і МЛУ (OR = 0,59; 95\% ДІ 0,37-0,94; $\mathrm{P}=0,028)$ у пацієнтів чоловічої статі, проте не впливав на показники інвазивності у жінок. Таким чином, виявлено статеві відмінності сироваткового вмісту ТТГ і частоти мікрокарцином, які були асоційовані з високою частотою супутнього AIT у жінок. Супутній AIT у чоловіків з ПРЩЖ був асоційований зі зниженням ризику екстратиреоїдного поширення і МЛУ, що може відображати захисну роль АIT в прогресуванні захворювання.

Ключові слова: папілярний рак щитоподібної залози; тиреотропний гормон; аутоімунний тиреоїдит; статеві розбіжності.

${ }^{1}$ Украӥнський науково-практичний иентр ендокринної хірургіі, Київ;

${ }^{2}$ Патоморфологічна лабораторія «CSD Health Care», Kü̈;

e-mailoksana.sulaieva@gmail.com

\section{REFERENCES}

1. Carling T, Udelsman R. Thyroid cancer. Annu Rev Med. 2014;65:125-37.

2. Karalus M, Tamatea JA, Conaglen HM et al. Rates of unsuspected thyroid cancer in multinodular thyroid disease. N Z Med J. 2018;131(1468):69-74.

3. Tang J, Liu HB, Yu L et al. Clinical-pathological characteristics and prognostic factors for papillary thyroid microcarcinoma in the elderly. J Cancer. 2018;9(2):256-62.

4. Arena S, Benvenga S. Gender-specific correlation of intranodular chronic lymphocytic thyroiditis with thyroid nodule size, echogenicity, and histologically-verified cytological class of malignancy risk. J Clin Transl Endocrinol. 2018;14:9-45.

5. Rahbari R, Zhang L, Kebebew E. Thyroid cancer gender disparity. Future Oncol. 2010;6(11):1771-9.

6. Yushi S, Hongjun L, Shaoqiang Z et al. Gender-specific risk of central compartment lymph node metastasis in papillary thyroid carcinoma Int $\mathrm{J}$ Endocrinol. 2018;2018:6710326.

7. Zamora-Ros R, Rinaldi S, Biessy C et al. Reproductive and menstrual factors and risk of differentiated thyroid carcinoma: the EPIC study. Int J Cancer. 2015;136(5):1218-27.

8. Genpeng L, Jianyong L, Jiaying $\mathrm{Y}$ et al. Independent predictors and lymph node metastasis characteristics of multifocal papillary thyroid cancer. Medicine (Baltimore). 2018;97(5):e9619.

9. Dorange A, Triau S, Mucci-Hennekinne S et al. An elevated level of TSH might be predictive of differentiated thyroid cancer. Ann Endocrinol-Paris. 2011;72(6):513-21.

10. Giswan KZ, Nielsen VE, Godballe C et al. Is serum TSH a biomarker of thyroid carcinoma in patients residing in a mildly iodine-deficient area? Endocrine. 2018;61(2):308-16.

11. Sulaieva O, Chernenko O, Chereshneva Y et al. Thyroid stimulating hormone levels and BRAFV600E mutation contribute to pathophysiology of papillary thyroid carcinoma: Relation to outcomes? Pathophysiology. 2019.

12. Gul K, Ozdemir D, Dirikoc A et al. Are endogenously lower serum thyroid hormones new predictors for thyroid 
malignancy in addition to higher serum thyrotropin? Endocrine. 2010;37(2):253-60.

13. Huang H, Rusiecki J, Zhao N et al. Thyroid-stimulating hormone, thyroid hormones, and risk of papillary thyroid cancer: A nested case-control study. Cancer Epidemiol Biomarkers Prev. 2017;26(8):1209-18.

14. Azizi G, Malchoff CD. Autoimmune thyroid disease: A risk factor for thyroid cancer. Endocr Pract. 2011; 17(2):201-9.

15. Lee IS, Hsieh AT, Lee TW et al. The association of thyrotropin and autoimmune thyroid disease in developing papillary thyroid cancer. Int J Endocrinol. 2017;2017:5940367.

16. Lloyd A. WHO classification of tumours of endocrine organs, 4th Edition, 2017.

17. AJCC Cancer Staging Manual, 8th Edition. Editors: Amin MB, Edge S, Greene F. et al. Springer, 2017.

18. Paparodis R, Imam S, Todorova-Koteva K et al. Hashimoto's thyroiditis pathology and risk for thyroid cancer. Thyroid. 2014;24(7):1107-14.

19. Noureldine SI, Tufano RP. Association of Hashimoto's thyroiditis and thyroid cancer. Curr Opin Oncol. 2015;27(1):21-5.

20. Resende de Paiva C., Grønhøj C., Feldt-Rasmussen U., von Buchwald C. Association between Hashimoto's thyroiditis and thyroid cancer in 64,628 patients. Front Oncol. 2017;7:53.

Received 28.05.2019 